\title{
Rage, loss and other footpaths: Subjectification, decolonisation and transformation in higher education
}

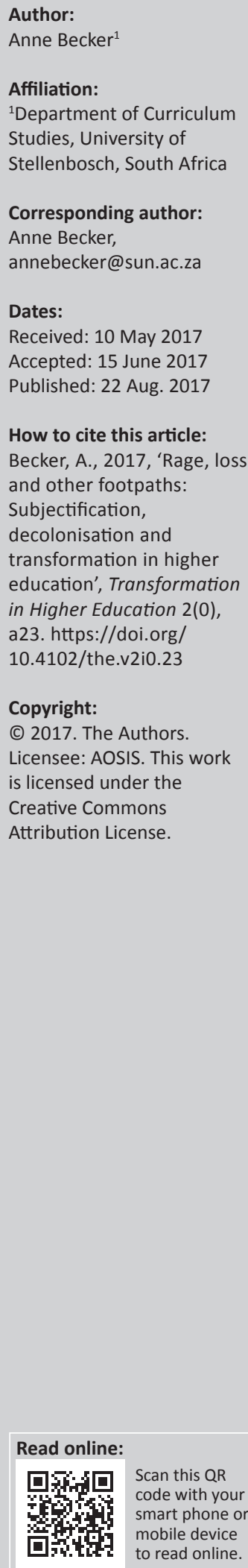

\begin{abstract}
The need to transform higher education in South Africa is indisputable. This article explores how the recent \#mustfall protests, as an Event, could inform transformation. An Event follows three phases: reframing (shattering the frame through which we understand reality), the fall (the loss of a primordial unity which is a retroactive illusion) and enlightenment (subjectivity itself as an eventuality). In conclusion, I pose that a shift towards who comes into presence in higher education and not (a pre-determined) what comes into presence, could provide possible footpaths to decolonialisation and transformation. Through processes of subjectification, the subject(s) of higher education could reframe historic ontological othering and actively take part in the process(es) of becoming and being human in higher education in (post)colonial South Africa.
\end{abstract}

\section{Introduction}

\begin{abstract}
'Is reconciliation in fact where we want to go? And even if it is must the road lead us so directly there?
Must we travel always and only on what we might want to think about as 'the national road?'

Is it not possible to turn off, to take an arterial route, perhaps even to visit some other destinations first?

What about the road to rage?

What about the barely visible footpath to sorrow, mourning and grief?' Thomas (2012)
\end{abstract}

Davids (2016:1) argues that 'universities, in their multiplex roles of social, political, epistemological and capital reform, are by their constitution expected to symbolise and enact transformation'. Although the need for transformation in higher education (hereafter HE) in South Africa seems indisputable, there seems to be a wide range of views on the nature, purpose(s) and process(es) of that transformation (Davids 2016; Du Preez, Simmonds \& Verhoef 2016; Heleta 2016; Ramathan 2016; Waghid 2016). This article explores the perspective on transformation the recent \#mustfall protests, as an Event (Žižek 2014), could provide.

The issues that led to the protests are complex. Du Preez, Simmonds and Chetty (2017) argue that a proper and full analysis can only be done after the discursive environments of the protests, as well as after the economic, political, psychosocial and historical intersections that influenced the protests have been explored. Clearly, this would be a major undertaking. The exploration in this article is limited to six themes suggested by Godsell et al. (2016:115-120), after documenting and analysing the \#mustfall protests. Their analysis includes data collected from acts of resistance (occupying, barricading, marches, toyi-toying, throwing stones and burning institutional structures and vehicles), and the use of social media (Twitter, Facebook), printed documents (press statements, court documents, open letters, worker documents, formal agreements) and art and music (fine art, poetry, theatre, music, songs, graffiti). The themes are: violence, \#FeesMustFall, Protest of shame, \#RainbowIsDead, \#Hope and \#Transformation.

I explore these themes in relation to Žižek's (2014) conceptualisation of an Event, grounding subjectification in colonial contexts in the theories of Fanon $(1967,2005)$ and Biesta $(2013)$. The notion of an event, for example, education as an event (Biesta 2013) and ethics as an event (Badiou 2002), has proved a useful lens. However, I have chosen to use Žižek's notion of the Event and the possibilities of transformation it presents to shed light on the current protest movement in South African HE (cf. Du Preez et al. 2017). For Žižek (2014:5), an Event can be material or immaterial, artistic, scientific, political and intimate. I explore the \#feesmustfall protests as a sociopolitical and educational Event.

At first glance, an Event is 'the effect that seems to exceed its causes' (Žižek 2014:3). One might argue that the literal 'falling' of the Rhodes statue and the effects did just that. The unexpected 
and unprecedented rapid spread, energy and power unleashed by the \#mustfall protests came as a shock to many South Africans. Finding terms to describe the \#mustfall phenomenon presented a challenge (Booysen 2016:2). Scholars positioned the student actions as uprisings or revolts. The students themselves used the term 'movement'. The movement includes protests such as: \#Rhodesmustfall, \#Rhodessowhite, \#OpenStellenbosch, \#transformWits, \#KingGeorgemustfall, \#thestatuemustfall, \#feesmustfall, \#nationalshutdown, \#feeswillfall, \#ANCmustfall, \#feeshavefallen, \#rapemustfall and \#patriachymustfall. I refer to the \#mustfall phenomenon as collective (although differentiated) protests.

In Žižek's view, an Event follows three phases: reframing (shattering the frame through which we understand reality) (Žižek 2014:10), the fall (the loss of a primodal unity which is a retroactive illusion) (Žižek 2014:49) and enlightenment (subjectivity itself as an eventuality) (Žižek 2014:76). In exploring subjectification, Biesta (2013:142) uses the notion of 'coming into presence'. To 'come into presence' describes the subject of education in relation to who comes into presence rather than what is to come, ought to come or is allowed to come into presence (Biesta 2013:142). This notion of who comes into presence is important in the context of transformation in HE. 'Coming into presence' concerns the subject(s) of higher education - not the nature, purpose(s) or process(es) of transformation. Significantly, subjectification is relational. The subject 'comes into presence' in the presence of others (ibid). In a similar vein, Fanon (1967:206) argues that the ideal of subjectification, inherent to freedom, can only be reached in the presence of, and for all of, humanity.

It is important to point out that although the \#mustfall protests have been described as a turning point in the South African sociopolitical and HE contexts, it is not possible to predict the full effect of the protests. Although the protests unleashed a new form of social and political power by challenging political order, institutional power and the social fibre of universities and society (Booysen 2016:22), the nature of an Event is that it changes the principles of change (Žižek 2014:3). This article therefore does not aim to speculate on the effects and consequences of the \#mustfall protests. Its aim is to explore the possibilities they create. I pose the following question: What possibilities do the \#mustfall protests, as an Event (Žižek 2014), present for rethinking transformation in South African HE?

Before exploring the \#mustfall protests in reference to the three stages of an Event, I situate HE and the \#mustfall protests within global and local intersections.

\section{Situating $\mathrm{HE}$ and the \#mustfall protests: A statement on the inability to start new}

South Africa's \#mustfall protests are positioned within intersections of global and local youth protests. In recent years, social critics, scholars and observers have been struck by the level and intensity of youth rebellion(s) all over the globe. In countries such as South Africa, Sri Lanka, Kenya, Venezuela, Chile and Egypt, it seems as if the 'lost generation' has risen from the dead (Jaramillo 2015:93). One of the reasons suggested for this phenomenon is a global revolt against liberal capitalist relations of exploitation, alienation and social and ecological devastation (ibid). Although the \#mustfall protests during 2015-2016 in South Africa intersect with global protests against neo-liberalism, capitalism, social inequality, lack of access to higher education and sociopolitical alienation, factors specific to the \#mustfall protests include coloniality and humanist othering, racism, whiteness, patriarchy, sexism and rainbowism (Booysen 2016:30).

HE in South Africa is positioned in the complex intersection and overlapping of global and local past, present and future place, space and time. Inherent in South Africa's apartheid and colonial legacy are humanist assumptions which classify and categorise humans and not-humans. The contesting of humanist white, Western and European frames of reason, excluding the Other and constructing meanings and understandings of humanity and reality, is central to the \#mustfall protests. The movement between past, present and future spaces of meanings and understandings remains evident in continuous othering and alienation in HE in South Africa (Roux \& Becker 2016). Keet (2014:26), with reference to Jensen, defines othering as the consequence of racism, sexism, classism and their intersections, which result in symbolic degradation and in turn influence processes of identity formation. Othering defines and constitutes the included in and the excluded from both place and space in HE.

The \#Rhodesmustfall movement that originated at the University of Cape Town was a powerful catalyst for the national movement. Žižek (2014) argues that the destruction of monuments, points to an inability to get rid of the past. In the South African context, the toppling of the Rhodes statue pointed to the impossibility of eradicating the objective violence of past legacies. This sparked a sequence of events that expressed the fundamental discontent of many students and staff in HE (Booysen 2016:3).

Global youth movements, protests and struggles are often successful when their goals relate to the broader society, rather than specifically youth-defined goals (Everatt 2016:127). Despite this, the 2015-2016 \#mustfall protests, which focused on student-related goals have achieved some success (ibid). In what follows, I explore the themes identified by Godsell and Chikane (2016) in relation to the three phases of an Event (Žižek 2014).

\section{Disruption and enframing: \#RainbowlsDead and the protest of shame}

According to Žižek (2014), an Event is unexpected (181), a radical turning point (179) and a reframing of reality (25). The first phase of an Event is therefore characterised by dissonance 
and disruption. Dissonance occurs when experiences relating to the world and others dis-order prior meanings and understandings (Jansen 2009:266). This dis-ordering, results in a paradoxical situation of unlearning and learning in which the self feels dis-connected from prior meaning or knowledge, but has not yet constructed new knowledge (Becker 2013:28). While dissonance results in feelings of discomfort or disagreement, disruption is an active process which interrupts and disrupts assumed and illusionary meanings and understandings (ibid).

South African society and HE in South Africa are trapped in what Žižek (2014:9) refers to as 'unknown knowns'. He poses that apart from the 'known knowns', 'known unknowns' and 'unknown unknowns', the 'unknown knowns' have the highest impact and possibilities for dissonance and disruption on societies (ibid). The 'unknown knowns' are the things we do not know that we know. Students, for example, might not 'know' the specifics of historic struggles and survival in South Africa but they carry with them thematic and meaning knowledge about conquest, humiliation, poverty, recovery, black and white, which is intellectual, emotional and partial (Jansen 2009:261). Using Lacan's notion of 'the knowledge which doesn't know itself', Žižek (2014:9) explains that this knowledge is the 'disavowed beliefs and suppositions we are not even aware of adhering to ourselves'. This knowledge has profound consequences for how we live, learn and see the world and others (Jansen 2009:261).

Thus, the only possibility of reframing is to become aware of 'unknown knowns', break the frame and allow a new relation to reality, premised on new knowledge, to be constructed. The first phase of the Event is not a 'change of reality but a change in the frame through which we perceive the world and engage with it' (Žižek 2014:10). It is a shift in our relationship to reality (Žižek 2014:32). Every individual constructs, frames and reframes reality through life experiences (cf. Heidegger 2010:148). Arendt (1994:20) argues: 'I do not believe that there is any thought process possible without personal experience. Every thought is an afterthought, that is a reflection on some matter or event'. The \#mustfall protests were a dissonant display and documentation of the lived experiences of middle class and poor students in South Africa, forcing South Africans to reflect, think and re-think the South African illusionary utopia.

Under apartheid, structural racism displayed clear lines of inequality. Although post 1994, legislation aimed to promote equality and the sense of a post-1994 society moving towards equality, the \#mustfall protests proclaimed that this aim had not translated into reality (Godsell et al. 2016:118). The protests illustrated the impossibility of poor black students and middle class students' competing in a market-driven society. The 'new' post-1994 middle class students also realised that they, in fact, were poor (Godsell et al. 2016:118). The illustration of their shame and their symbolic naked poverty dissolved the frame through which South Africans viewed economic progress and the rise of the black middle class. Students illustrated this with slogans such as: Are the rich the only academically deserving and Post racism society says 'you are poor go get a degree'. Colonial elitist Universities says 'you are too poor to take you out of poverty' \#WeAreFucked \#ShutItDown (Godsell et al. 2016:117). Waghid (2016), with reference to Agamben's notion of denudation, posits that transformation can be enacted 'through an unconcealed disclosedness, that is, an unveiling of the self in which visibility and presence (nudity) hold sway'. Within such a process, humans (i.e. students during the \#mustfall protests) risk baring their nakedness to each other and reflect on the possibility of a new relation. This, however, requires a reciprocal unveiling from all involved in the process of transformation (Waghid 2016).

The \#mustfall protests disrupted the illusion of a utopian, equal and dignified post-1994 South Africa. It shattered the illusion of the rainbow nation 'living democratically ever after' (Dlamini 2010:12; Godsell et al. 2016:118). For the protesting students rainbowism is dead. The shattering of assumptions that democracy would bring social justice and equality was central to the protests. During the protests, photographs showed how white students formed a human shield around black students reminding South Africans that the past is never dead. Remembering the June 1976 protests when school children in Soweto, as Gordimer (2011:261) puts it 'learned the terrible lesson of white power', both black students and white students instinctively knew whose bodies are 'allowed to exist without violence and questioning' (Godsell et al. 2016:118).

\section{Loss and fall: Ontological othering, the negative container and \#feesmustfall}

The second phase of the Event is characterised by loss; the loss implied in a disrupted and shattered illusion of a present and future South Africa and the loss of a relation with an assumed reality that never existed. During the second phase of the Event, a 'rupture in the normal run of things' occurs (Žižek 2014:38). Žižek (2014:49) refers to the moment of rupture as the fall. He poses that it is the loss of some primordial unity and harmony which never existed, which is just a retroactive illusion' (ibid). During the process of rupture, the Event moves from 'Event as reframing - as a shift in our relationship to reality - to Event as a radical change of this reality itself' (Žižek 2014:32).

For Žižek (2014:34), a fall has three elements. First, there is a rational formal structure, and, second, an atemporal classification of a totality into humans and not-humans. Atemporal classification of humans in this way has its roots in ancient Greece where humans were classified as either Greek or Barbarians. 'Barbarians' was a 'container' for all who were not-Greek (Žižek 2014:33). Third, there is a temporal actualisation of humans and not-humans in contingent material reality. The negative container of nothumans is historically inscribed in the rational formal structure and continually intervenes to enact the fall. The 
imploding of the formal structure into contingent material reality is therefore inevitable (Žižek 2014:35). It is a historic and continual enactment by those bundled into the negative container (ibid). This can be illustrated by the imploding of humanism, enacted by the negative container of not-humans, which has resulted in the recent global, non-human turn and the post-human shift (cf. Braidotti 2013:13).

The fall of humanism into itself and its enactment by the negative container in material reality are mirrored in the \#feesmustfall protests. Within the historic enlightenment humanist structure, the negative container contains those who escape the structure of white (not-white), European (not-European) and male (not-male). Since the Enlightenment, the historical development of the humanist model shaped the idea of Europe as the One with universalising powers, selfreflexive reason and the hegemonic cultural model (Braidotti 2013:13). During the \#mustfall protests, the negative container of sexualised, racialised, colonial, sociopolitical and economic others pierced and disrupted the humanist ideal of who and what is human and whose bodies matter.

Gordimer (2011:375) argues: 'In the official South African consciousness, the ego is white: it has always seen all South Africans as ordered around that'. Within colonial contexts saturated by Eurocentric humanism, the 'human' is not an objective statistical average, but a measure of sameness through which others are allotted a designated category and positioned in specific social locations (Braidotti 2013:25). The historic enlightenment white, male, propertied human is thus not only posited as the One entitled to the rights of humans (Kapur 2006), he is also posited as a categorical and qualitative standard, opposing the sexualised, racialised, naturalised other - the nothuman (Braidotti 2013:26). The \#mustfall protests are driven by the negative container consisting of not-humans in (post)colonial and neo-liberal contexts.

The historical positioning of 'African' during colonialism and apartheid has set up colonial and racialised othering as a conceptual and practical category (Keet 2014:25). Derrida and Kamuf (1985:292) in Racism's Last Word pose that the word apart-heid, 'concentrates separation, raises it to another power and sets separation itself apart'. By isolating being apart as an essence, the word itself 'corrupts it into a quasi-ontological separation' (Derrida \& Kamuf 1985:292). Othering in HE, Keet (2014:26) therefore argues, is both ontological and epistemological as epistemic 'othering' is both a precursor and a consequence of ontological separation. The \#mustfall protests put the 'othered' experiences of the negative container, within white institutions, in the spotlight (Godsell \& Chikane 2016:58). The call for radical decolonisation, the removal of historic symbols, the language debate, a revised curriculum and the empowerment of black students and staff is meant to address colonial and racialised ontological and epistemological othering.

Intersecting with colonial and racial othering is sexualised othering. Spelman (2005:355) poses that sexism historically existed before racism. Women and the LGBTIAQ+ (Lesbian, Gay, Bisexual, Transgender, Intersex, Asexual, Queer and other sexual orientations and gender identities) communities were a visual and often raging presence in the protests. In the tradition of the humanist positioning of the white male as fully human and women, black people and members of the LGBTIAQ+ as not-male and not-white, they are stereotyped and assumed to be not-human (ibid). Black women, in particular, are positioned within interrelated experiences of classism, racism and sexism (hooks ${ }^{1}$ 2005:345). Black women cannot just be female - she is female and black (Spelman 2005:356). It is ironic that during the protests, female activists were othered and marginalised by their male counterparts, adding layers of othering to the already othered negative container (Du Preez et al. 2017).

Classism as a category of othering also featured prominently in the protests. Becker and Du Preez (2016) argue that educational systems and structures saturated in capitalist and neo-liberal ideologies normalise and reproduce exclusions. Inequality in schooling is reproduced in post-school education which is then reproduced in the broader society (Pillay 2016:268). Exclusion and growing inequality have multilayered effects for poor and middle class students: unaffordable fees are an entry barrier and rising fees result in debilitating student debt further contributing to the reproduction of inequality (Pillay 2016:268).

In sum, the negative container of sexualised, racialised, colonial, sociopolitical and economic others pierced and disrupted the illusionary post-1994 'primordial unity and harmony' (Žižek 2014). The protests forcibly moved 'Event as reframing - as a shift in our relationship to reality - to Event as a radical change of this reality itself' (Žižek 2014:32). Booysen (2016:28-39) argues that the protests forced the government to reconsider policies, forced budgetary restructuring and cemented the power of direct action (as opposed to voting) as a means of engagement with the government. By doing this, the \#mustfall protests added a new axis to public protests in South Africa (Booysen 2016:30).

\section{Enlightenment: Violence, subjectification, \#Transformation and \#Hope}

The fall is a traumatic experience (Žižek 2014:78). It is the traumatic intrusion of something new which is unacceptable from a dominant view and causes feelings of extreme loss, division, hatred and violence. It brings a division between those who want to uphold the status quo and those who see the need for change (Žižek 2014:185). Not only do the \#mustfall protests symbolise the divide between categories of who and what constitutes human and who belongs in the negative container, but the negative container is also internally divided. Deep divisions within the student body and between

1.Gloria Jean Watkins is a world renowned scholar in feminism and social activism and goes by the pen name bell hooks. The unconventional lowercasing of her name is done intentionally to signify the nature of her work. 
students and university management, government, society and the police force also resulted from the protests.

These divisions are crucial to the project of finding a new unity. Out of the trauma, the post-traumatic subject and possibilities of a new unity emerge (Žižek 2014:76). The post-traumatic subject is a subject who survived the trauma of violent external intrusions and traumas which 'destroy the symbolic structure of the subject's identity' (Žižek 2014:95, 96). Žižek (2009b), however, concedes that the posttraumatic subject is mostly a Western luxury. He poses that there can be no post-traumatic subjects in many African countries, because in (post)colonial contexts the trauma of colonialisation is ongoing. For the traumatised subject to become a post-traumatic subject, the cause of the trauma needs to be resolved.

For Fanon (in Bird-Pollen 2015:159), resolving the cause of the trauma entails aggressive counter-violence and striving for a new humanity. Fanon (2005:231) and Lee (2015:157) argue that counter-violence in a colonised context is a conscious action towards the eradication of colonial identities, the possibility of subjectivity and a new humanism defined outside of European othering. Godsell et al. (2016:115) argue that although violence had no hashtag, the 'possibility of violence, the prevention of violence, what constitutes violence, the causes and effects of violence and the fear of violence all permeated the protests'. Jansen (2017) argues that violence on South African campuses became routine, repeatable, predictable and sustainable, fitting the definition of institutionalisation.

Violence in South Africa cannot be understood outside of South Africa's violent history (Jansen 2017).

In exploring the violence associated with the protests, a distinction needs to be made between subjective and objective violence. The violent acts of students such as stoning, burning and vandalising property constitute subjective violence. Subjective violence is perpetrated by identifiable agents and is perceived from a non-violent zero point - an irrational explosion of violence against a background of normality and peace (Žiźek 2009a:1-2). The unexpected and unpredictable violent nature of the \#mustfall protests happened against the zero point of a constitutional democracy and the inclusion of all South Africans in the Bill of Rights (1996). The normalised zero point is sustained by invisible symbolic and systemic objective violence (Žiźek 2009a:2).

Subjective and objective violence are interrelated. Both rely on principles of separation. Perpetrators of subjective violence frame their targets by 'setting a group apart as the enemy' (Jansen 2017:247), such as non-protesting students and staff, or the management of white colonial universities. Symbolic objective violence concerns the violence inherent to language and meaning and the framing of others as separate from self. It points to relations of social dominance and their imposition on the universe of meaning, resulting in, for example, sexist, humanist, apartheid and colonial othering, exclusions and marginalisation. Systemic violence concerns the functions of economic and political systems such as the effects of neo-liberal (classism) and political alienation (Žiźek 2009a:1). For (post)colonial subjects to eradicate subjective and objective violence and move towards subjectification and renewed unity with others, there needs to be an engagement with the conflict between renunciation and selfconsciousness inherent in freedom (Fanon 1967:206).

The conflict between renunciation and self-consciousness is inherent in the process of decolonisation and crucial to subjectification and freedom (cf. Fanon 2005:228). From the very beginning of colonisation, decolonisation has been the project of the colonised. Fanon (2005:228) defines the initial quest for equality and freedom in the Freudian sense of replacement. He argues: 'The native [sic] is the oppressed person whose permanent dream is to become the persecutor'. In the Freudian notion of the Oedipus complex, the confrontation between son and father is characterised by aggression. During the process of replacement, the son first becomes indifferent to the father and then seeks to replace him (Bird-Pollen 2015:157). The quest to replace, according to Fanon (1967:192), should go beyond mere replacement towards the ideal of living in self-consciousness instead of bare existence.

It is important to note, as Lee (2015:188) points out, that Fanon was never a one-dimensional advocate of violence. His writings were informed by a profound respect for people suffering oppression, a radical empathy and a love for humans (Lee 2015:191). At the end of Black Skin, White Masks, Fanon (1967) muses:

It is through self-consciousness and renunciation, through a permanent tension of this freedom, that man can create the ideal conditions of existence for a human world.

Superiority? Inferiority?

Why not simply try to touch the other, feel the other, discover the other?

Was my freedom not given me to build the world of you, man [sic]? (p. 206)

The process of subjectification towards 'building the world of you, man [sic]' (Fanon 1967:206) is a process of becoming and being a subject of action and responsibility (Biesta 2013:141). Biesta (2013:20) defines the process of subjectification as double-sided. There is the subjectivity of self, defined with reference to the other: unique-in-difference. Secondly, there is the subjectivity of self where uniqueness matters. Self depends on the unique and irreplaceable other within the process of subjectification. This is because, uniqueness-as-irreplaceable becomes uniqueness-as-responsibility towards inter-subjectivity, mutual recognition and mutual freedom (ibid). It is only by being recognised as human by the other that selfconsciousness becomes possible. Fanon (1967:190) poses: 'his [sic] human worth and reality depends on this other and on his recognition by the other. It is in this other that the meaning of life is condensed'. The need for recognition does not concern itself with what the self is: the colonial subject wants herself to be recognised (Fanon 1967:191). 
During 28 individual encounters and 7 group discussions with student leaders at the University of the Free State between November 2011 and December 2012, Keet and Nel (2016) found that one of the issues of major concern to student leaders was 'not being recognised'. They argue that, in the context of HE in South Africa, recognition was mainly based on subjects' status as subjects of human rights and the law; recognition of what they are. This, they conclude, can only result in misrecognition as it is based on the alienating principles of law (Keet \& Nel 2016:134). Furthermore, recognition only premised on principles of law or human rights may well add to the stabilising of objective violence in institutional cultures of HE in South Africa.

Recognition in HE requires acknowledging who the subjects of HE are: fully human included in an inclusive humanity (cf. Fanon 1967:190). In striving towards this ideal, the subject of HE therefore risks going beyond mere life towards an ideal: the ideal of breaking the cycle of oppression and the birth of a new human world, 'a world of mutual recognition' (Fanon 1967:192). This cannot be done for the subject by merely announcing that colonialism is no more. The subject needs to develop the desire to be recognised as fully human and to risk life and education in pursuit of this (Biesta 2013; Fanon 1967:197). For Biesta (2013:xii), education towards subjectification is 'a beautiful risk'.

The risk towards a human world requires reciprocal risktaking and unveiling from all involved (Waghid 2016). All subjects of HE should come into presence so that 'they recognise themselves as mutually recognising each other' (Hegel in Fanon 1967:191). Within this process, they risk baring their nakedness to each other and reflect on the possibility of a new relation (Waghid 2016). Through the acknowledgement of the naked other, once new knowledge is constructed, a new relationship with reality becomes possible. In analysing social media content, Godsell et al. (2016:118) identify hope as one of the themes of the \#mustfall narrative. Hope is embodied in tweets between students such as: 'Another world IS possible' (@Anele_Nzimande, 30 October 2015, in Godsell et al. [2016:118]).

When the ideals of subjectification, decolonisation and transformation are ethical, the colonial subject becomes the origin of a new relation between humans premised on an inclusive human ontology. Decolonisation then seeks to unify the world not by simply replacing the colonial master, but by overcoming that which the colonial master represents (BirdPollen 2015:155). The ontological and epistemological divisive colonial relation is replaced with a relation premised on mutual respect and recognition (ibid).

\section{Concluding remarks}

This article explores the ways in which the \#mustfall protests, as an Event (Žižek 2014), could inform rethinking of transformation in HE in South Africa. I highlight four aspects. Firstly, the need for something new in HE is indisputable. Something new, in terms of an Event, however, needs to be qualified. During an Event, transformation should not be understood within a modernist paradigm of continual renewal perceived on an upwards curve (Becker 2017). Within a modernist conception of renewal, transformation happens within a stable context with stable constants against which transformation can be measured. The unexpected and unpredictable reframing and changing of reality, which an Event enables, challenges such possibilities.

Renewal is understood as a double-sided and continually changing organic process in an Event. An Event, Žižek (2014:180) argues, gives rise to the commitment of a collective subject to a new transformative or emancipatory project. Although the original transformation ideals might unite a collective, the transformative ideals need to be continually transformed to prevent the transformation process from becoming impotent (Žižek 2014:184). There should thus be continual transformation of transformation ideals. The continually changing demands of students illustrate this. An Event changes the principles of change from a single and linear process to interrelated, multi-layered, organic and continually shifting processes. The breaking away, the starting new, therefore not only refers to the initial collective decision to transform towards assumed ideals but should also speak to the continual and radical transformation of ideals during the transformation process.

Related to the above is the second aspect: moving towards ethical ideal(s). Du Preez et al. (2017) argue for an 'ethical approach at a time when critical transformation of higher education is urgently needed'. The ethical or the 'ethic of truth', they argue, with reference to Badiou's notion of ethics as event, emerges not from a current situation (such as the situation in HE) but from the event when the boundaries of the situation are pierced. In the context of the \#mustfall protests, they argue, the struggle would then be a striving towards finding 'a good way of being' towards which the collective should stay true (Badiou 2002:1; Du Preez et al. 2017). The subjects of decolonisation and transformation in HE should continually redefine their ethical ideal(s) as they come into presence and recognise each other as fully human. There can be no pre-determined 'good way of being'.

In the third place, ethical transformation should be concerned with the subjects of $\mathrm{HE}$ and their mutual recognition as irreplaceable and unique-in-responsibility. It should primarily focus on who comes into presence rather than what is to come, ought to come or is allowed to come into presence (Biesta 2013:142). Transformation through subjectification is actional, and the subjects of transformation need to become and be unique subjects of action and responsibility (Biesta 2013:141; Fanon 1967:191). Decolonisation within a transformative framework should therefore not concern itself with what the self is or should be or what HE is or should be: the (post) colonial subjects want themselves to be recognised in HE (Fanon 1967:191). This implies, in the last instance, the necessity for historic ontological othering, within an enlightenment humanist paradigm, to be rejected. The 
rejection of the historic negative container provides possibilities of finding alternative schemes of thought, and of thinking critically about who and what the human in becoming is in (post)colonial contexts (cf. Braidotti 2013:11).

Individual subjectification of the (post)colonised subject will not guarantee political or social decolonisation or the decolonisation of HE (Bird-Pollen 2015:151). It is, however, impossible to attain any decolonisation without the reconstitution of the psyche as autonomous and decolonised. Although the Oedipal paradigm is characterised by the desire to have the power to dominate the master and not to share power, this negativity and aggression is a key element of a free society (Bird-Pollen 2015:151-152). It is a constant engagement with the conflict between renunciation and self-consciousness inherent in freedom. It is only by confronting this conflict and working towards a new humanity that the self (and HE) can engage with subjectification, decolonisation, freedom and ethical ideal(s) (Fanon 2005:228, 1967:206).

\section{Acknowledgements Competing interests}

The author declares that she has no financial or personal relationships that may have inappropriately influenced her in writing this article.

\section{References}

Arendt, H., 1994, Essays in understanding, 1930-1954, Schocken Books, New York. Badiou, A., 2002, Ethics: An essay on the understanding of evil, Verso, London.

Becker, J.A., 2013, 'Curriculum and intra-dialogical spaces: Consciousness and becoming in identity construction based on human rights values', unpublished $\mathrm{PhD}$, North West University, Potchefstroom.

Becker, A., in press, 'Moral responsibility and human rights: Speaking to the "dark side of human rights"', South African Journal of Higher Education.

Becker, A. \& Du Preez, P., 2016, 'Ideological illusions, human rights and the right to education: The in(ex)clusion of the poor in post-apartheid education', Journal of Education 64, 55-76.

Biesta, G.J.J., 2013, The beautiful risk of education, Routledge, New York.

Bird-Pollen, S., 2015, Hegel, Freud and Fanon: The dialectic of emancipation, Rowman \& Littlefield, London.

Booysen, S., 2016, 'Two weeks in October: Changing governance in South Africa', in S. Booysen (ed.), Fees must fall: Student revolt, decolonisation and governance in South Africa, pp. 22-52, Wits University Press, Johannesburg.

Braidotti, R., 2013, The posthuman, Polity Press, Cambridge.

Davids, N., 2016, 'On extending the truncated parameters of transformation in higher education in South Africa into a language of democratic engagement and justice', Transformation in Higher Education 1(1), a7. https://doi.org/10.4102/the.v1i1.7

Derrida, J., \& Kamuf, P., 1985, 'Racism's last word', Critical Inquiry 12(1), 290-299. https://doi.org/10.1086/448331

Dlamini, J., 2010, Native nostalgia, Jacana, Auckland Park.
Du Preez, P., Simmonds, S. \& Verhoef, A.H., 2016, 'Rethinking and researching transformation in higher education: A meta-study of South African trends', Transformation in Higher Education 1(1), a2. https://doi.org/10.4102/the.v1i1.2

Du Preez, P., Simmonds, S. \& Chetty, J., in press, 'Critical transformation in higher education: Ethical reflections on \#Mustfall movements and concomitant genderbased violence', South African Journal of Higher Education.

Everatt, D., 2016, 'Standing on the shoulders of giants? Successive generations of youth sacrifice in South Africa', in S. Booysen (ed.), Fees must fall. Student revolt decolonisation and governance in South Africa, pp. 126-147, Wits University Press, Johannesburg.

Fanon, F., 1967, Black skin, white masks, Grove Press, New York.

Fanon, F., 2005, 'The wretched of the earth', in E.C. Eze (ed.), African philosophy: An anthology, pp. 228-233, Blackwell, Malden.

Godsell, G., \& Chikane, R., 2016, 'The roots of the revolution', in S. Booysen (ed.) Fees must fall: Student revolt, decolonisation and governance in South Africa, pp. 54-73, Wits University Press, Johannesburg.

Godsell, G., Lepere, R., Mafoko, S. \& Nase, A., 2016, 'Documenting the revolution', in S. Booysen (ed.), Fees must fall. Student revolt, decolonisation and governance in South Africa, pp. 101-124, Wits University Press, Johannesburg.

Gordimer, N., 2011, Telling times: Writing and living 1950-2008, Bloomsbury, London.

Heidegger, M., 2010, 'The age of the world picture', in G. Delanty \& P. Strydom (eds.), Philosophies of social sciences: The classic and contemporary readings, pp. 147-151, Open University Press, Berkshire.

Heleta, S., 2016, 'Decolonisation of higher education: Dismantling epistemic violence and Eurocentrism in South Africa', Transformation in Higher Education 1(1), a9. https://doi.org/10.4102/the.v1i1.9

hooks, B., 2005, 'Black women: Shaping feminist theory', in E.C. Eze (ed.), African philosophy: An anthology, pp. 338-345, Blackwell, Malden.

Jansen, J.D., 2009, Knowledge in the blood: Confronting race and the apartheid past, Stanford University Press, Stanford.

Jansen, J.D., 2017, As by Fire: The end of the South African University, Tafelberg, Cape Town.

Jaramillo, N.E., 2015, 'The art of youth rebellion', Curriculum Inquiry 45(1), 92-105. https://doi.org/10.1080/03626784.2014.995064

Kapur, J., 2006, 'Human rights in the 21st century: Take a walk on the dark side', Sydney Law Review 28, 665-687.

Keet, A., 2014, 'Epistemic "othering" and the decolonising of knowledge', Africa Insight 44(1), 23-37.

Keet, A. \& Nel, W., 2016, 'Rights, regulation and recognition: Studying student leaders' experiences of participation and citizenship within a South African University', International Journal of Educational Sciences 13(1), 129-144.

Lee, C.J., 2015, Franz Fanon: Towards a revolutionary humanism, Jacana, Auckland Park.

Pillay, P., 2016, 'Financing of universities: Promoting equity or reinforcing inequality', in S. Booysen (ed.), Fees must fall: Student revolt, decolonisation and governance in South Africa, pp. 256-268, Wits University Press, Johannesburg.

Ramathan, L., 2016, 'Beyond counting the numbers: Shifting higher education transformation into curriculum spaces', Transformation in Higher Education 1(1), a6, 1-8. https://doi.org/10.4102/the.v1i1.6

Roux, C. \& Becker, A., 2016, 'Humanising higher education in South Africa through dialogue as praxis', Educational Research for Social Change 5(1), 131-143. https:// doi.org/10.17159/2221-4070/2016/v5i1a8

Spelman, E.V., 2005, 'The erasure of black women', in E.C. Eze (ed.), African philosophy: An anthology, pp. 355-359, Blackwell, Malden, MA.

Thomas, K., 2012, 'Photography, apartheid, and the "road to reconciliation"', in H. Binoe (ed.), Transition, \#107: Blending Borders, pp. 79-89, Indiana University Press, Indiana.

Waghid, Y., 2016, 'Transformation as an act of denudation: A response to Petro du Preez, Shan Simmonds and Anné Verhoef', Transformation in Higher Education 1(1), a3. https://doi.org/10.4102/the.v1i1.3

Žižek, S., 2009a, Violence, Profile Books, London.

Žižek, S., 2009b, 'Living dead' Vampire terminology, viewed 22 March 2017, from https://youtu.be/yGkxFgzvHM

Žižek, S., 2014, Event, Penguin Random House UK, London. 